\title{
Sodium Dynamics in Pyramidal Neuron Dendritic Spines: Synaptically Evoked Entry Predominantly through AMPA Receptors and Removal by Diffusion
}

\author{
(Denichi Miyazaki ${ }^{1,2}$ and (D)William N. Ross ${ }^{1,2}$ \\ ${ }^{1}$ Department of Physiology, New York Medical College, Valhalla, New York 10595, and ${ }^{2}$ Marine Biological Laboratory, Woods Hole, Massachusetts 02543
}

Dendritic spines are key elements underlying synaptic integration and cellular plasticity, but many features of these important structures are not known or are controversial. We examined these properties using newly developed simultaneous sodium and calcium imaging with single-spine resolution in pyramidal neurons in rat hippocampal slices from either sex. Indicators for both ions were loaded through the somatic patch pipette, which also recorded electrical responses. Fluorescence changes were detected with a high-speed, low-noise CCD camera. Following subthreshold electrical stimulation, postsynaptic sodium entry is almost entirely through AMPA receptors with little contribution from entry through NMDA receptors or voltage-gated sodium channels. Sodium removal from the spine head is through rapid diffusion out to the dendrite through the spine neck with a half-removal time of $\sim 16 \mathrm{~ms}$, which suggests the neck has low resistance. Peak $\left[\mathrm{Na}^{+}\right]_{\mathrm{i}}$ changes during single EPSPs are $\sim 5 \mathrm{~mm}$. Stronger electrical stimulation evoked small plateau potentials that had significant longer-lasting localized $\left[\mathrm{Na}^{+}\right]_{\mathrm{i}}$ increases mediated through NMDA receptors.

Key words: AMPA receptor; dendrite; hippocampus; NMDA receptor; sodium imaging; spine

\section{Significance Statement}

Dendritic spines, small structures that are difficult to investigate, are important elements in the fundamental processes of synaptic integration and plasticity. The main tool for examining these structures has been calcium imaging. However, the kinds of information that calcium imaging reveals is limited. We used newly developed, high-speed, simultaneous sodium and calcium imaging to examine ion dynamics in spines in hippocampal pyramidal neurons. We found that following single subthreshold synaptic activation most sodium entry was through AMPA receptors and not through NMDA receptors or through voltage-gated sodium channels and that the spine neck is not a significant resistance barrier. Most spine mechanisms are linear. However, regenerative NMDA conductances can be activated with stronger stimulation.

\section{Introduction}

Dendritic spines are the sites of synaptic contacts among many neurons in the CNS and are key elements responsible for synaptic integration and cellular plasticity. Because of their small size, these spines have not, with one recent exception (Jayant et al., 2017), been studied with direct electrical recordings. Instead, their properties have been inferred either by recordings from nearby dendrites, or by imaging voltage-sensitive dye (VSD)

\footnotetext{
Received June 23, 2017; revised Aug. 18, 2017; accepted Aug. 28, 2017.

Author contributions: K.M. and W.N.R. designed research; K.M. performed research; K.M. and W.N.R. analyzed data; K.M. and W.N.R. wrote the paper.

This work was supported in part by National Institutes of Health Grants R21NS085729 and R01NS099122. We thank llya Fleidervish, John Lisman, and Thomas Oertner for comments on the manuscript.

The authors declare no competing financial interests.

Correspondence should be addressed to William N. Ross, Department of Physiology, New York Medical College, Valhalla, NY 10595. E-mail: ross@nymc.edu.

DOI:10.1523/JNEUROSCI.1758-17.2017

Copyright $\odot 2017$ the authors $\quad 0270-6474 / 17 / 379964-13 \$ 15.00 / 0$
}

changes or the $\left[\mathrm{Ca}^{2+}\right]_{\mathrm{i}}$ changes in the spines evoked by synaptic transmission or direct stimulation. VSD recordings from spines are technically challenging, but are beginning to produce results (Palmer and Stuart, 2009; Popovic et al., 2015; Acker et al., 2016). Spine-calcium measurements, primarily with two-photon microscopy (Yuste and Denk, 1995; Sabatini et al., 2002), have been the main approach to examining spine properties. The $\left[\mathrm{Ca}^{2+}\right]_{i}$ changes themselves are important because they activate key enzymes and are implicated directly in the induction of several forms of plasticity. They also, indirectly, give information about the channels activated by synaptic transmission and mechanisms regulating the potential change in the spines. However, there are some limitations to these calcium measurements. Only some of the channels [NMDA receptors and voltage-gated calcium channels (VGCCs)] are permeable to calcium, so activation of other channels and receptors on pyramidal neuron spines, like AMPA receptors and voltage-gated sodium channels (VGSCs), cannot be directly examined with this approach. Also, calcium is not a 
A
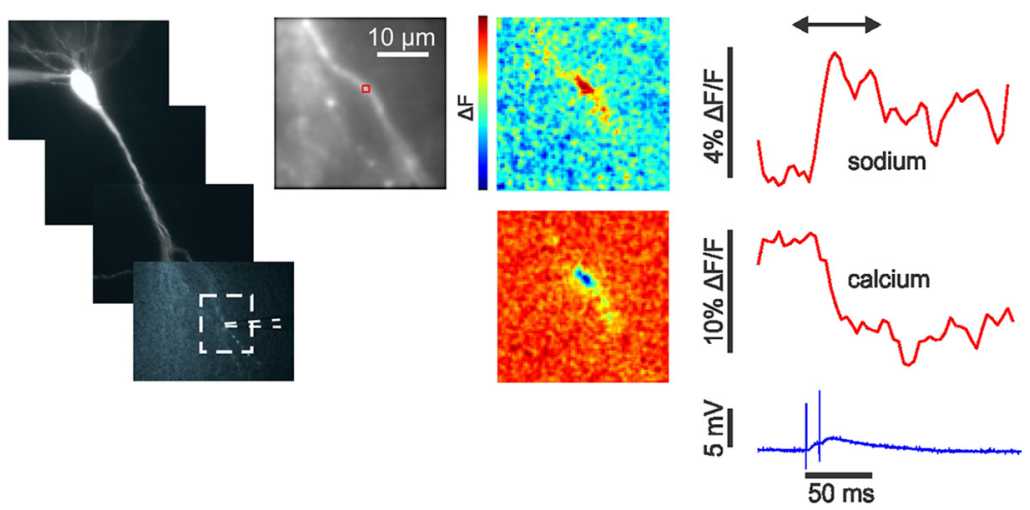

B
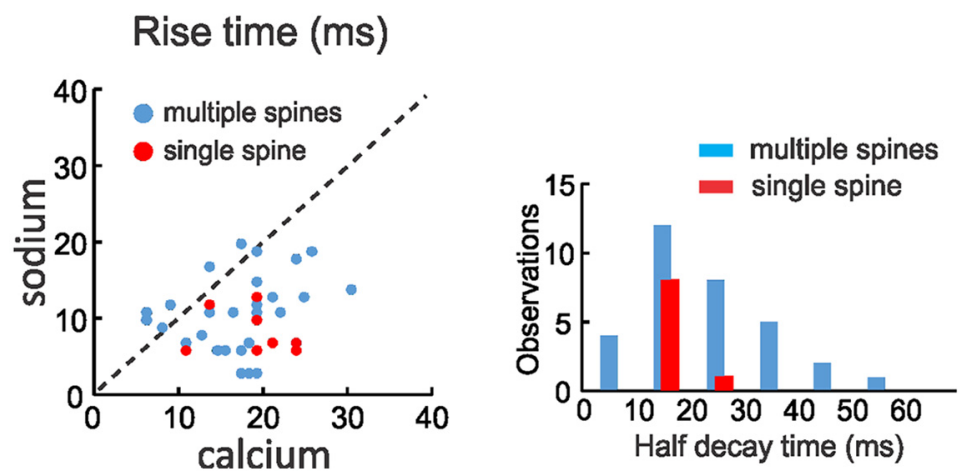

Figure 1. Synaptic activation evokes localized $\left[\mathrm{Na}^{+}\right]_{\mathrm{i}}$ and $\left[\mathrm{Ca}^{2+}\right]_{\mathrm{i}}$ changes in pyramidal neuron dendrites. $\boldsymbol{A}$, Image of pyramidal neuron filled with ANG-2 from the patch pipette on the soma. The positions of the stimulating electrode and the region in the expanded panel are shown. The traces to the right show the sodium signal (increasing ANG-2 fluorescence) and the calcium signal (decreasing bis-fura-2 fluorescence) measured from the red ROI that includes several spines. In this and all other figures the pseudocolor difference images (between the times at the ends of the arrows above the traces) show the peak change in fluorescence, $\Delta F$, for all positions in the image field. The color bar scale ranges from the minimum to maximum value (also in all other figures). The largest changes are in a restricted region on the dendrite. Simultaneously, the synaptic potential in response to two stimuli $10 \mathrm{~ms}$ apart is shown below. $\boldsymbol{B}$, Left, The $10-90 \%$ rise times for a series of trials in difference cells are plotted against each other. The blue dots are from experiments as in $\boldsymbol{A}$; the red dots are from single-spine experiments in Figure 4 . There is some scatter but almost all calcium rise times are slower than sodium rise times. $\boldsymbol{B}$, Right, There is a wide distribution of sodium signal decay times (blue bars) but almost all are faster than $50 \mathrm{~ms}$ with a peak near $15 \mathrm{~ms}$. The red bars are from the single-spine experiments in Figure 4. There is less variation in the rise times and half-decay times from single-spine signals than from signals from larger areas.

significant charge carrier in synaptic activation, so measurements of $\left[\mathrm{Ca}^{2+}\right]_{\mathrm{i}}$ changes cannot easily reveal information about the amplitude and time course of electrical events in spines. In addition, calcium is often highly buffered by indicator molecules, which distorts the amplitude and time course of spine $\left[\mathrm{Ca}^{2+}\right]_{i}$ changes.

Dynamic sodium imaging in spines can overcome some of these limitations. It directly gives information about all major charge carriers in the spine since calcium influxes are relatively small and do not contribute significantly to potential changes unless they are regenerative. Also, sodium ions are not buffered either endogenously or by indicators, so the magnitude and time course of the indicator changes reflects the dynamics of this ion. In addition, the best sodium indicators [sodium-binding benzofuran isophtalate (SBFI) and ANG-2] are low-affinity indicators, which makes the fluorescence changes linear with changes in $\left[\mathrm{Na}^{+}\right]_{\mathrm{i}}$.

Fluorescence measurements of sodium dynamics in axons and dendrites have been recorded (Lasser-Ross and Ross, 1992; Callaway and Ross, 1997; Rose et al., 1999; Knöpfel et al., 2000; Kole et al., 2008; Bender and Trussell, 2009; Fleidervish et al., 2010). One paper reported sodium measurements in groups of spines using two-photon microscopy (Rose and Konnerth, 2001). However, this study did not have the time resolution or sensitivity to follow the dynamics in individual spines. We recently reported improvements in these measurements that allow this level of precision (Miyazaki and Ross, 2015). In addition, we developed an excitationswitching technique to simultaneously measure $\left[\mathrm{Na}^{+}\right]_{\mathrm{i}}$ and $\left[\mathrm{Ca}^{2+}\right]_{\mathrm{i}}$ changes in individual spines with high time resolution (Miyazaki and Ross, 2015). With this approach, we now have determined the following: (1) that following simple synaptic activation, the main source of $\left[\mathrm{Na}^{+}\right]_{\mathrm{i}}$ increases in spines is entry through AMPA receptors, while the contribution of sodium entry through NMDA receptors is relatively small; (2) that sodium entry through VGSCs is insignificant and calcium entry through VGCCs is much smaller than through NMDA receptors; (3) that the main removal mechanism for sodium ions is diffusion through the spine neck, reducing the peak $\left[\mathrm{Na}^{+}\right]_{\mathrm{i}}$ to half amplitude in $\sim 16$ ms; this rapid diffusion is consistent with a low neck resistance; (4) that a single EPSP generates a $\left[\mathrm{Na}^{+}\right]_{\mathrm{i}}$ change of $\sim 5 \mathrm{~mm}$ in the spine head, which may double the resting concentration; and (5) that longer-lasting and larger $\left[\mathrm{Na}^{+}\right]_{\mathrm{i}}$ increases are observed following regenerative NMDA-receptor activation.

\section{Materials and Methods}

Slice preparation and electrophysiological procedures. Most experiments used hippocampal slices (300 $\mu \mathrm{m}$ thick) from 2-4-week-old Sprague Dawley rats of either sex prepared using protocols standard for our laboratory (Miyazaki and Ross, 2015). All procedures were approved by institutional animal care and use committees at New York Medical College and the Marine Biological Laboratory. Submerged slices were placed in a chamber mounted on a stage rigidly bolted to an air table and were viewed with water-immersion lenses in an Olympus BX50WI microscope mounted on an $X-Y$ translation stage. For maximum light detection and spatial resolution, we used an Olympus $60 \times, 1.1$ numerical aperture lens. Even with this high numerical aperture lens, it was possible to patch neurons under visual control. Slices were superfused at $1 \mathrm{ml} / \mathrm{min}$ with standard ACSF consisting of the following (in mM): $124 \mathrm{NaCl}, 2.5$ $\mathrm{KCl}, 2 \mathrm{CaCl}_{2}, 2 \mathrm{MgCl}_{2}, 1.25 \mathrm{NaH}_{2} \mathrm{PO}_{4}, 26 \mathrm{NaHCO}_{3}, 0.01 \mathrm{D}$-serine, and 10.1 glucose. In approximately half of the experiments, we used ACSF with $1 \mathrm{~mm} \mathrm{MgCl}$ to reduce the $\mathrm{Mg}^{2+}$ block of the NMDA receptors. This concentration is used in many slice experiments and is close to the measured concentration in the CNS (Ding et al., 2016). Where significant, this change in $\mathrm{Mg}^{2+}$ concentration is noted in the Results. Somatic whole-cell recordings were made using patch pipettes pulled from 1.5mm-outer-diameter thick-walled glass tubing (1511-M, Friedrich \& Dimmock). Tight seals on CA1 pyramidal cell somata were made with the "blow and seal" technique using video-enhanced differential interference contrast optics to visualize the cells (Stuart et al., 1993). This camera (INFINITY3S-1URM, Lumenera) was also used to take highresolution fluorescence images of the cell at the end of the experiment. 
For most experiments, the pipette solution contained the following (mM): 130 potassium gluconate, $4 \mathrm{Mg}$-ATP, 0.3 GTP-Tris salt, and 10 HEPES, 7 potassium phosphocreatine, $\mathrm{pH}$ adjusted to 7.3 with $\mathrm{KOH}$. This solution was supplemented with different indicator combinations, which were matched with different pairs of LEDs: SBFI (sodium) and OGB-1 or fluo-5F (calcium), matched with 385 and 460 nm LEDs; bis-fura-2 or fura-FF (calcium) and ANG-2 (sodium), matched with 385 and 520 nm LEDs; SBFI and ANG-2 (both sodium), matched with 385 and $520 \mathrm{~nm}$ LEDs; and bisfura- 2 and fluo-5F (both calcium), matched with 385 and $460 \mathrm{~nm}$ LEDs. The most common combination was $300 \mu \mathrm{M}$ bis-fura-2 and 200$400 \mu \mathrm{M}$ ANG-2 (see Results). The high concentration of bis-fura- 2 in these experiments was chosen to aid the visualization of thin oblique dendrites, but certainly increased the buffering of calcium ions. Even though this pipette solution contained almost no sodium, it is unlikely that the internal $\left[\mathrm{Na}^{+}\right]_{\mathrm{i}}$ at the synapse was significantly changed from the normal resting value since a change would require dialysis of the synapse from the distant patch pipette on the soma. Also, the membrane ion pumps are likely to be the dominant regulators of resting $\left[\mathrm{Na}^{+}\right]_{\mathrm{i}}$ away from the cell body. Experiments were done at room temperature $\left(\sim 24^{\circ} \mathrm{C}\right)$. All indicators were obtained from Invitrogen except ANG-2, which was obtained from Teflabs. Other drugs were obtained from Sigma-Aldrich and Tocris Bioscience.

Data taking and analysis. For simultaneous sodium and calcium imaging, we used the apparatus previously described in detail (Miyazaki and Ross, 2015). Experiments were under the control of Neuroplex software, which came with the RedShirtImaging NeuroCCD-SMQ camera. This program determined the frame rate and resolution of the camera (typically $80 \times 80$ pixels at $500 \mathrm{~Hz}$; i.e., $250 \mathrm{~Hz}$ in each channel), synchronized the recording of electrical and optical signals, controlled the initiation of the LED pulse sequence, and triggered a Master- 8 pulser, which in turn controlled the timing and duration of intrasomatic pulses and activated a synaptic stimulation protocol in some experiments. The resulting optical and electrical data were then processed through a custom Matlab program, SCANDATA, written in our laboratory. As described by Miyazaki and Ross (2015), this program separated the two data streams and aligned the sodium and calcium signals with voltage and current recordings from the soma. The optical signals were corrected for nonconstancy of the LED intensity during a sweep by normalizing to the intensity at the corner of the image field, away from the imaged dendrite. In some traces, an additional, smaller correction for indicator bleaching was applied by normalizing to the intensity during a sweep without stimulation. With careful attention to avoid unnecessary illumination of the slice, we typically were able to make 5-10 trials of $200 \mathrm{~ms}$ duration before noticing signs of photodynamic damage. This limitation sometimes prevented us from doing a complete washout in pharmacological experiments. When comparing signals over many trials, we corrected for movement of the slice by registering images to a fiduciary mark, usually a dendritic spine. Occasionally, spatial and/or temporal filters were applied as indicated in the Results.

Calibration of indicators. To simultaneously calibrate SBFI and ANG-2 inside pyramidal neurons, we slightly modified the procedures of Rose et al. (1999). External solutions contained the following (in mM): $170\left(\mathrm{Na}^{+}+\right.$ $\mathrm{K}^{+}$), 140 gluconate, 10 HEPES, $\mathrm{pH} 7.3$, and $3 \mu \mathrm{M}$ gramacidin $\mathrm{D}, 10 \mu \mathrm{M}$ monensin, and $100 \mu \mathrm{M}$ ouabain. Gramacidin D and monensin are ionophores, to make the membrane permeable to sodium, and oubain blocks

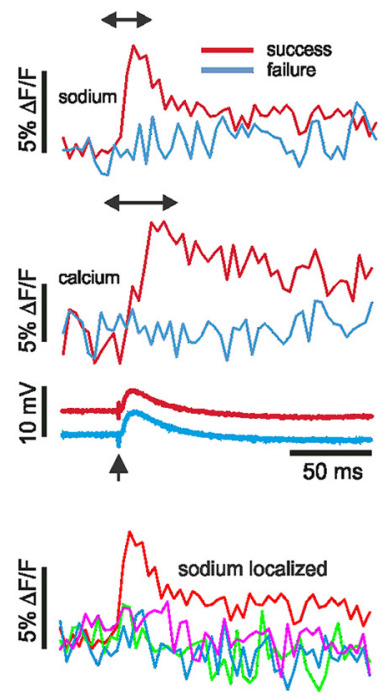

B

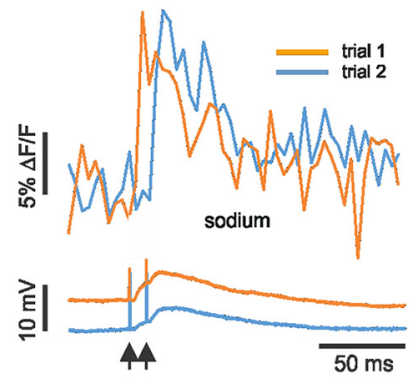

C

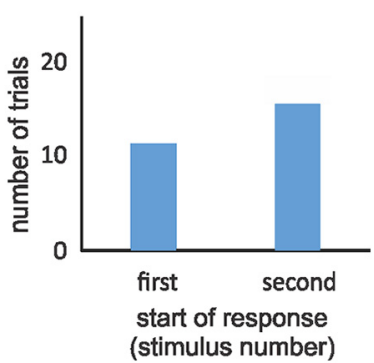

Figure 2. $\quad\left[\mathrm{Na}^{+}\right]_{\mathrm{i}}$ and $\left[\mathrm{Ca}^{2+}\right]_{\mathrm{i}}$ changes following synaptic activation of a single spine. $\boldsymbol{A}$, Signals from two trials are shown from (he pixel placed on a spine head at the center of a cluster marked on the cell image. A magnified image of this spine region expectations. ACSF contained $2 \mathrm{~mm} \mathrm{Mg}^{2+}$. $\boldsymbol{B}$, Two trials from a similar experiment on a different cell. The sharp rise of the spine additional spines beyond the illustrated one. C, Histogram showing which stimulus generated a response in 26 selected trials from single-spine experiments. Trials that were ambiguous are not included. Success on the second stimulus was more likely.

the $\mathrm{Na}^{+}-\mathrm{K}^{+}$pump. Together they allow the internal $\left[\mathrm{Na}^{+}\right]_{\mathrm{i}}$ to follow the external concentration. The patch pipette contained both $2 \mathrm{~mm}$ SBFI and $200 \mu \mathrm{M}$ ANG-2. After filling the cells with these indicators, we used the excitation switching technique to measure the resting fluorescence at a location on the main dendrite near the soma. Background fluorescence was subtracted from a nearby location. This procedure was repeated for a series of external sodium concentrations. Further details are given in the Results.

Statistics. Errors in the text are SD unless indicated otherwise. Statistical differences between groups were calculated using Student's $t$ test; $p$ values are indicated in the figure legends.

\section{Results}

We patched the cell bodies of CA1 pyramidal neurons in the upper part of the hippocampal slice. After waiting $\sim 30 \mathrm{~min}$ for the indicators to diffuse into the dendrites, we searched for a dendritic branch close to the surface of the slice. During this step, we were careful to use only brief illumination to minimize photodynamic damage to the cell. Then we positioned the $\theta$-glass electrode close to a secondary branch (within $20 \mu \mathrm{m}$ ). We gave one or two brief ( $200 \mu \mathrm{s}, 10 \mathrm{~ms}$ apart) stimulation pulses to the slice. The current usually was adjusted to keep the subsequent EPSPs below the threshold for the generation of postsynaptic spikes. If necessary, a small $(\sim 10 \mathrm{mV})$ hyperpolarization was added through the somatic electrode. Simultaneously, we looked for fluorescence changes in the two channels. All signals were blocked by $1 \mu \mathrm{M}$ TTX $(n=3)$ showing that they were evoked by generating action potentials in presynaptic fibers. 
A

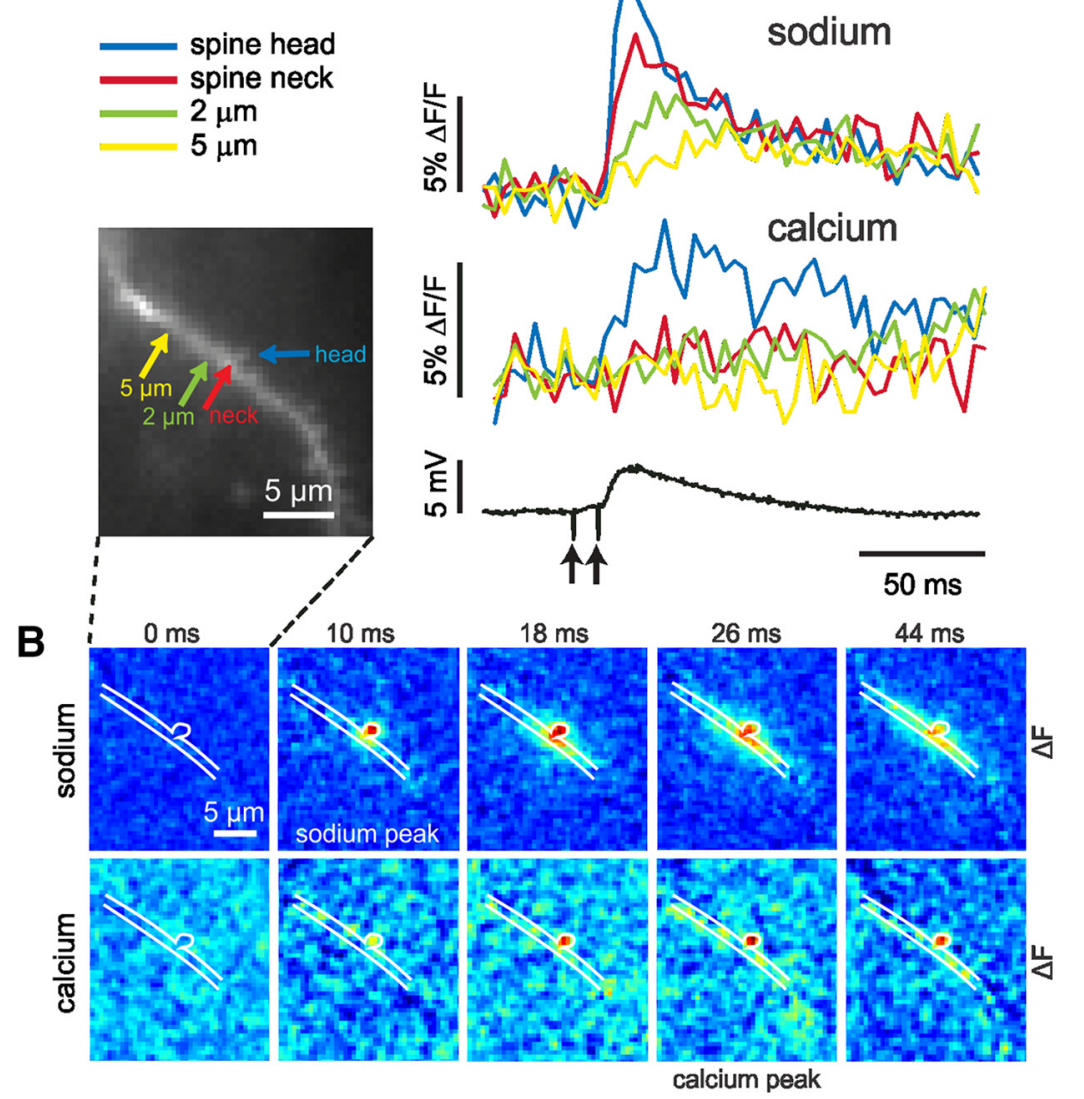

Figure 3. Single-spine experiment where the spread of sodium to the dendrite could be observed. $A$, Two-pulse synaptic stimulation generated sodium (ANG-2) and calcium (bis-fura-2) changes. Four locations on the dendritic region are marked. Sodium changes were detected from the spine head, spine neck, and two close dendritic regions. The largest and fastest signal was from the spine head. The dendritic signals were clearly smaller and slower. In contrast, a $\left[\mathrm{Ca}^{2+}\right]_{i}$ change was only detected from the spine head. ACSF contained $2 \mathrm{~mm} \mathrm{Mg}^{2+}$. B. A selection of simultaneous movie frames of sodium and calcium difference images from this same experiment referenced to the time of the second stimulus $(0 \mathrm{~ms})$. The sodium sequence reached a peak at $10 \mathrm{~ms}$ and was largely confined to the head and neck at that time. At later times spread into the dendrites was detected. The calcium sequence shows a peak response at $26 \mathrm{~ms}$, which remained confined to the spine head.
$30 \mu \mathrm{m}$ found previously in comparable experiments (Rose and Konnerth, 2001), probably because our measurements were more sensitive, allowing us to use weaker stimulation to evoke detectable $\left[\mathrm{Na}^{+}\right]_{\mathrm{i}}$ changes. Even so, most responses were larger than expected for a single spine so we call them "multiple-spine" responses as in Figure $1 B$.

Figure $1 B$ compares the rise times of the sodium and calcium signals for a representative selection of events $<5 \mu \mathrm{m}$. For this plot, we included experiments where we used either 1 or $2 \mathrm{mM} \mathrm{Mg}^{2+}$ since there was no statistical difference between the two sets of data (data not shown). The rise times of the sodium signals were faster than the calcium signals even though there was some variation among experiments (average values: sodium, $12.0 \pm 5.7$ $\mathrm{ms}, n=37$; calcium, $17.6 \pm 8.1 \mathrm{~ms}, n=$ $31)$. For comparison, we measured signals from single intrasomatically evoked action potentials (measured either in the axon hillock or proximal dendrites) and found rise times for sodium $2.85 \pm 1.0 \mathrm{~ms}$ $(n=7$; measured at 250 and $500 \mathrm{~Hz})$ and for calcium $4.6 \pm 0.5 \mathrm{~ms}(n=3$; measured at $250 \mathrm{~Hz}$ ). These low values show that the slower rise times of the synaptic signals were real and not affected by our apparatus. We also plotted the half-decay times of the sodium signals, which were generally $<50 \mathrm{~ms}$ with a peak near $15 \mathrm{~ms}$, again with wide variation. We did not plot the calcium decay times since they were influenced by indicator buffering and saturation (Neher and Augustine, 1992; Helmchen et al., 1996).
Figure $1 A$ shows the results of a typical trial showing simultaneous optical and electrical recording. Following synaptic stimulation, the fluorescence of ANG-2 (sodium indicator) increased and the fluorescence of bis-fura-2 (calcium indicator) decreased, corresponding to increases in $\left[\mathrm{Na}^{+}\right]_{\mathrm{i}}$ and $\left[\mathrm{Ca}^{2+}\right]_{\mathrm{i}}$. In both channels, the onset was within a one-frame interval ( $4 \mathrm{~ms}$ ) following the stimulus artifact. The rise time (10-90\%) of the ANG-2 (sodium) signal was $\sim 12 \mathrm{~ms}$; the rise time of the bisfura-2 (calcium) signal was slower, even though partial saturation of this indicator accelerates the apparent time to peak. The pseudocolor difference images (measured from a time before the stimulus to a time just after the peak of the signals) shows that the signals were localized to a region of $\sim 5 \mu \mathrm{m}$ along the dendrite. There were a variety of responses in different experiments. In some cases, there were no signals; in others, signals were detected in only one channel; and in still others, signals were found in both channels. In the last category, there were signals that extended over different spatial extents. If we consider only events where the EPSP did not evoke spikes and events where plateau potentials (see Fig. 10) were not generated, then $\sim 95 \%$ of events from sodium measurements and $\sim 70 \%$ from calcium measurements had a spatial extent of $<6 \mu \mathrm{m}$ at the time of peak response. These signals were considerably more localized than the average size of

\section{Single-spine responses}

There are a variety of potential reasons for the heterogeneity in time courses. In some cases, we could see spines on the dendrites; in others, the spines were not visible. Even in cases where we saw spines, it is likely that many other spines were not clearly visible. Therefore, in most experiments it was difficult to determine whether the signals came from the spines, nearby dendrite, or both. This problem was compounded by light scattering in the tissue and out-of-focus elements. Furthermore, we could not easily determine how many presynaptic fibers were activated even though the responses on the dendrite were often patchy, suggesting activation of separate spines by different presynaptic fibers.

Although we could not predict in advance whether an individual trial would activate a single spine or whether that spine would be visible, we were, over time, able to acquire a collection of seven neurons with nine apparent spines that met those two criteria. Figure $2 \mathrm{~A}$ shows one of these cells. Single synaptic stimulation evoked very localized sodium and calcium signals that originated from an identified spine. Almost no sodium increase was detected from nearby pixels away from the spine. No signals in either channel were detected in a subsequent trial even though the somatic EPSP was almost unchanged. This all-or-none response is consistent with activation of a single synapse. In other 
experiments where we gave two stimuli, we sometimes detected sodium signals following the first stimulus and, in other trials, following the second stimulus (Fig. $2 B)$. This variation reflects the well known low probability of transmitter release at single pyramidal neuron synapses (Allen and Stevens, 1994; Sabatini et al., 2002). Responses starting on the second stimulus were detected with slightly greater frequency (58\%; Fig. 2C). This greater success was possibly due to presynaptic facilitation (Stevens and Wang, 1995; Oertner et al., 2002) and not the generation of an NMDA spike (Schiller et al., 2000; Chalifoux and Carter, 2011) since 3-[(6)-2carboxypiperazin-4-yl]-propyl1-phosphonic acid (CPP) did not block the sodium signal (see Fig. 7). To improve the success rate in the experiments, we adopted a protocol using two stimuli separated by 10 or $12 \mathrm{~ms}$.

In several cells, we detected singlespine signals that also showed dendritic responses. One example is in Figure 3. The sodium signal (ANG-2 fluorescence) rose sharply over the spine and decayed rapidly (half-decay time, $\sim 13 \mathrm{~ms}$ ). In locations over the base of the spine and nearby dendrites, the sodium signals rose more slowly and decayed more slowly than the spine signal. The spine calcium signal (bisfura-2 fluorescence) rose and fell more slowly than the spine sodium signal. The calcium signal was almost undetectable in the two dendrite locations. A selection of movie frames for this sequence is shown in Figure $3 B$. The sodium and calcium signals serve as internal controls for each other. Since the calcium signal was confined to the spine, we know that there was no significant light scattering into the dendrite in this cell. Therefore, the sodium signals measured in the dendrite are real and not due to scattering from the spine, a point reinforced by the different time courses of the responses in the two compartments. Similarly, our detection of sodium signals in the dendrites shows that we could detect signals in this compartment in this cell. Therefore, the absence of a calcium signal in the dendrite shows that there really was little or no dendritic calcium in this trial (Yuste and Denk, 1995; Bloodgood and Sabatini, 2007).

The spatial extent of these nine identified spine responses was comparable to the dimensions of a spine (Fig. $4 A$ ). The width of the sodium signals was $1.3 \pm 0.2 \mu \mathrm{m}(n=9)$ and the width of the calcium signals was $1.3 \pm 0.4 \mu \mathrm{m}(n=8$; in one measurement, the calcium signal was undetectable). The true size was probably smaller than these dimensions because of light scattering in the tissue and because the pixel size was $0.4 \mu \mathrm{m}$. Remarkably, the time courses of the signals from these spines were almost identical

A

B

D
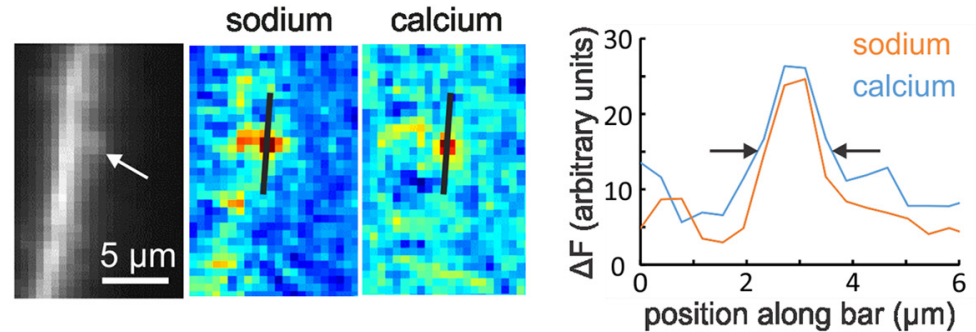

C
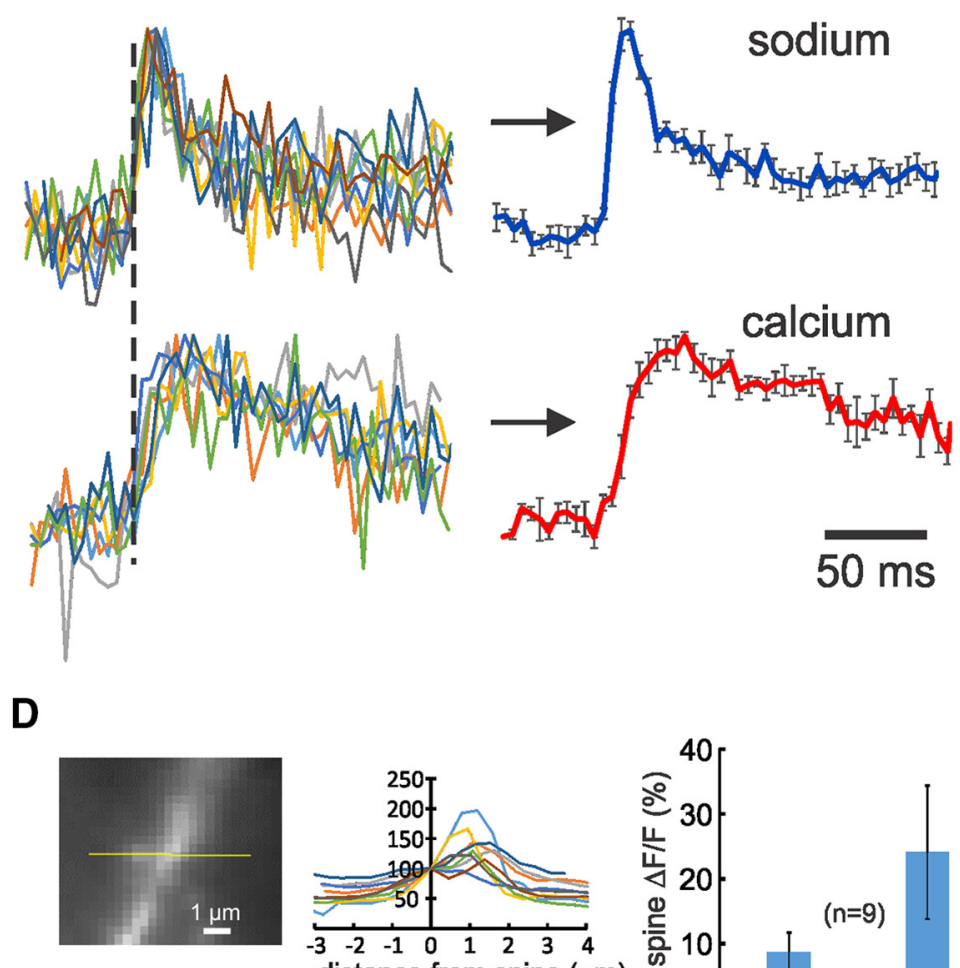
distance from spine $(\mu \mathrm{m})$

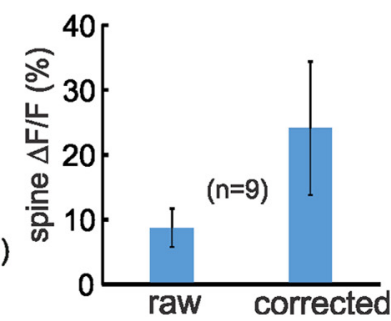

Figure 4. Synaptically activated sodium and calcium signals from spine locations have stereotyped time courses and large amplitude. $\boldsymbol{A}$, Spatial extent of single-spine signals. The image shows a dendrite with an identified spine. The pseudocolor images show the spatial distributions of the ANG-2 and bis-fura- 2 fluorescence changes following synaptic stimulation. The right panel shows the fluorescence changes along the black lines on the images. The arrows define the locations where the changes were half-maximum. The steps are pixels $(0.4 \mu \mathrm{m})$. $\boldsymbol{B}$, Normalized overlay of nine sodium signals and eight calcium signals from identified spines following synaptic stimulation. In five trials, two stimuli, $10 \mathrm{~ms}$ apart, were given; in the other four trials, only a single stimulus was given. To compensate for the variation shown in Figure $2 B$, all sodium traces were aligned with the start of the rising phase of the signals (dotted line); the individual calcium traces followed the alignment of their respective sodium traces. Clearly the heterogeneity of these time courses is less than the heterogeneity of the signals not derived from identified spines (Fig. $1 B)$. C, Averages of these signals. Clearly the sodium signals have very fast rise and decay times; the calcium signals are slower. D, Left, Profiles of fluorescence levels through these nine spines. Image of cell in Figure $2 A$. Values are normalized to $100 \%$ at the center of the spine; the dendrites are to the right and usually have higher values; background is to the left and varies between 41 and $85 \%$ of the spine value. $D$, Right, Histogram of $\Delta F / F$ values as measured (raw) and after estimated background levels were subtracted from the measured $F$ values (corrected).

(Fig. 4B). The normalized average of these signals (Fig. 4C) shows that the sodium signal in the spine rose rapidly in $8.6 \pm 2.7 \mathrm{~ms}$. The true rise time may have been even faster since the sampling interval of $4 \mathrm{~ms}$ filtered the response. This fast rise time is consistent with the short duration of the AMPA component of the EPSC (Sah et al., 1990). The signals decayed to half-maximum amplitude in $16.6 \pm 4.5 \mathrm{~ms}$ (Fig. $4 C$ ). We detected similar fast sodium time courses in five other cells, but could not clearly 
A
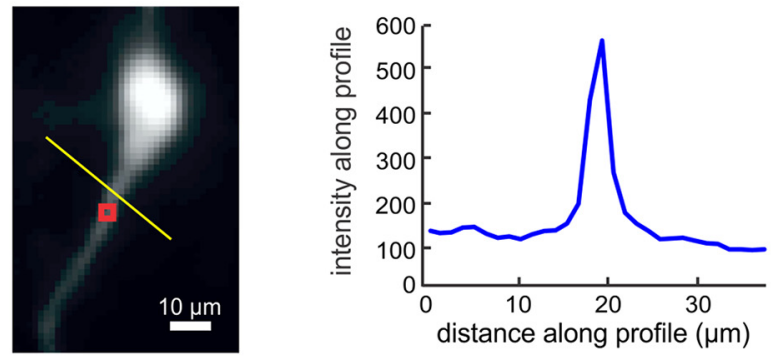

B

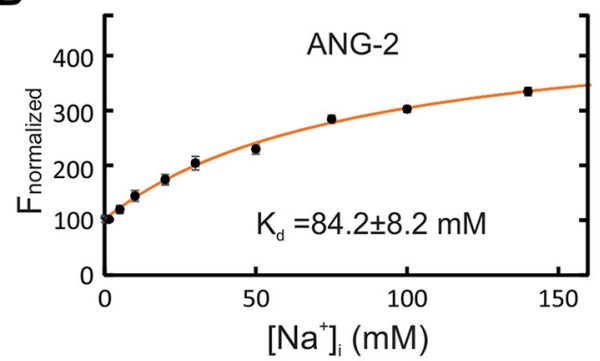

$$
\left[N a^{+}\right]_{i}=K_{d}\left(\frac{F_{\max }-F}{F-F_{\min }}\right)
$$

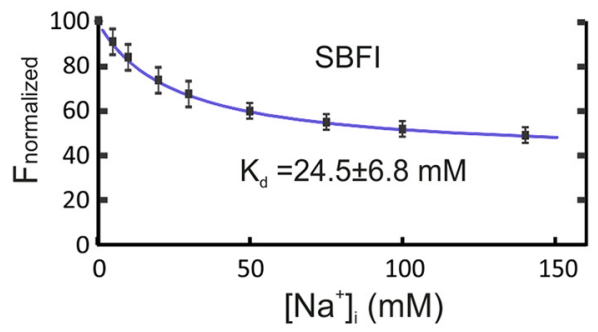

Figure 5. Calibration of SBFI and ANG-2. A, Image of the proximal part of a pyramidal neuron filled with these indicators (excitation at $385 \mathrm{~nm}$ to excite SBFl; excitation at $520 \mathrm{~nm}$ generates an analogous image of ANG-2 fluorescence). The red ROI shows the region at the base of the dendrite where measurements were made. The trace to the right shows the profile of fluorescence levels along the yellow line in the image. The background level is $\sim 25 \%$ of the peak on the dendrite. $\boldsymbol{B}$, Measurements of the fluorescence intensity at the $\mathrm{ROI}$ at both excitation wavelengths as solutions were changed, varying the external $\left[\mathrm{Na}^{+}\right]_{\mathrm{i}}$. In each case, the background fluorescence, estimated from a location away from the cell, was subtracted (Fig. 5A). Results were averaged from nine cells, normalizing the intensity for SBFI at $0 \mathrm{~mm}$ and the intensity for ANG-2 at $100 \mathrm{~mm}$. These values were fit to the single-wavelength formula (Grynkiewicz et al., 1985) shown on the figure, yielding the indicated $K_{d}$ values.

assign them to identified spines even though the responses also were localized, probably because the spines were under or over the dendrite. The calcium signals all rose more slowly, with a time to peak of $19.6 \pm 4.9 \mathrm{~ms}$.

These records lead to three conclusions: (1) synaptically activated calcium signals are largely confined to spines, a result consistent with many previous experiments [Yuste and Denk, 1995; Kovalchuk et al., 2000; activation of extrasynaptic receptors (Chalifoux and Carter, 2011) are not significant in our conditions]; (2) the fast rise and fast fall of spine sodium signal represents the true kinetics of the sodium signal in that location (if there were any buffering of sodium by ANG-2, then the sodium kinetics in the spine would be even faster); (3) the smaller amplitude and slower kinetics of the dendrite sodium signals suggests that they could come from diffusion of sodium out of the spine. Similarly, the restriction of calcium signals to the spines indicates that the slow dendritic sodium signals are not due to direct activation of extrasynaptic NMDA receptors.

The peak ANG-2 fluorescence change for EPSP-evoked signals in these nine spines ranged from 6.4 to $15.6 \%$ (\% $\Delta F / F$ : average, $8.7 \pm 3.0)$. We corrected these values to subtract background fluorescence (Fig. $4 D$ ), which was variable and often difficult to determine. After the correction, the $\% \Delta F / F$ values ranged from 12 to 45 (average, $24.1 \pm$ 10.3). We estimated the sodium concentration changes corresponding to these fluorescence changes using the calibration procedure described in Materials and Methods. We found (Fig. 5) that the fluorescence values as a function of $\left[\mathrm{Na}^{+}\right]_{\mathrm{i}}$ fit the single wavelength formula described for fura-2 (Grynkiewicz et al., 1985). From these curves, we determined that the equilibrium dissociation constant $\left(K_{\mathrm{d}}\right)$ for SBFI was $24.5 \pm 6.8$ and the $K_{\mathrm{d}}$ for ANG-2 was $84.2 \pm 8.3$. The $K_{\mathrm{d}}$ for SBFI is close to the value of $26 \mathrm{~mm}$ determined previously (Rose et al., 1999), which gives us confidence that our procedure with single-photon excitation and background subtraction (which was not necessary with two-photon excitation) is accurate. We also determined the maximum change in fluorescence, $\left(F_{\max }-\right.$ $\left.F_{\text {min }}\right) / F_{\text {min }}$. This value depends on the apparatus and the spectra of the indicators. Using our excitation filters, we found this value was 3.7 for ANG-2 and 0.56 for SBFI. With these calibrations, a $10 \%$ change in fluorescence corresponds to 4.6 $\mathrm{mm}$ (SBFI) and $2.3 \mathrm{~mm}$ (ANG-2). These values are valid even when the change is not from a resting concentration of $0 \mathrm{~mm}$ (e.g., when starting from a resting concentration of $10 \mathrm{~mm}$ ), since they are calculated at the lower range of values where the curves are linear. Using this calibration, we estimate that a single EPSP generates a peak $\left[\mathrm{Na}^{+}\right]_{\mathrm{i}}$ increase of $5.7 \pm 2.4$ $\mathrm{mm}$ in a spine.

Source of sodium and calcium changes Synaptically activated increases in $\left[\mathrm{Na}^{+}\right]_{\mathrm{i}}$ could come from three sources: entry through AMPA receptors (as suggested above), entry through NMDA receptors, or entry through VGSCs. The very fast rise time of the spine sodium signal suggests that they could come from either spine AMPA receptors or spine VGSCs, both of which would generate rapid signals since the activated conductances are very brief (Sah et al., 1990). To test this idea, we applied $5 \mu \mathrm{M}$ CNQX, a specific AMPA-receptor blocker. Figure $6 A$ shows an example of this experiment and Figure $6 B$ shows summary data. In this figure and in Figure 7, the small ROIs include several spines; we assume that all the spines are responding similarly to the blockers. CNQX completely blocked the $\left[\mathrm{Na}^{+}\right]_{\mathrm{i}}$ increase and blocked most of the $\left[\mathrm{Ca}^{2+}\right]_{\mathrm{i}}$ increase. The latter result is consistent with the result of some previous experiments (Emptage et al., 1999; Yuste et al., 1999), although others found that there was less blockage of the $\left[\mathrm{Ca}^{2+}\right]_{i}$ increase (Kovalchuk et al., 2000). A standard interpretation (Yuste et al., 1999) of this experiment is that CNQX blocks the AMPA receptors, which blocks the EPSP. Since some depolarization is needed to relieve the $\mathrm{Mg}^{2+}$ block of the NMDA receptors, it is reasonable to conclude that CNQX would block most of the subthreshold $\left[\mathrm{Ca}^{2+}\right]_{\mathrm{i}}$ and sodium increase. To test whether we could detect sodium entry through NMDA receptors, we repeated the experiment with CNQX in ACSF containing zero 
$\mathrm{Mg}^{2+}$ (see Fig. 10C). In this case, synaptic stimulation generated large sodium signals, which lasted much longer than the signals in ACSF with 1 or $2 \mathrm{mM} \mathrm{Mg}^{2+}$. These signals probably reflect the entry of sodium through NMDA receptors, which are open at resting potential in this condition.

In parallel experiments, we found that NMDA-receptor blockage by $10 \mu \mathrm{M}$ CPP eliminated almost $90 \%$ of the postsynaptic $\left[\mathrm{Ca}^{2+}\right]_{\mathrm{i}}$ increase, measured with bisfura-2, but on average only blocked $\sim 20 \%$ of the $\left[\mathrm{Na}^{+}\right]_{\mathrm{i}}$ increase (Fig. $7 A, B$ ); there was little change to the EPSP. To compare with other work (Bloodgood et al., 2009), we repeated these experiments using the less saturating indicator fluo-5F, together with bis-fura-2 in the same pipette (Miyazaki and Ross, 2015), and obtained the same result (Fig. 7C). These pharmacological experiments are consistent with almost all of the $\left[\mathrm{Na}^{+}\right]_{\mathrm{i}}$ increase coming via sodium entry through AMPA receptors and almost all of the $\left[\mathrm{Ca}^{2+}\right]_{i}$ increase coming through NMDA receptors. Therefore, the EPSP primarily reflects sodium entry through AMPA receptors.

Another possibility is that some of the subthreshold sodium increase comes from sodium entry through VGSCs, mediated either by sodium spikes confined to spines (Segev and Rall, 1988; Araya et al., 2007) or persistent sodium currents activated by the synaptic potential (Mittmann et al., 1997). There are several arguments that indicate that this pathway is insignificant. First, in previous experiments it was determined that trains of backpropagating action potentials (bAPs) make small $\left[\mathrm{Na}^{+}\right]_{\mathrm{i}}$ increases in the dendrites compared with the axon or soma (Jaffe et al., 1992; Rose et al., 1999; Fleidervish et al., 2010). We repeated those earlier experiments, which were done with the sodium indicator SBFI, with new experiments using ANG-2 (Fig. 8A). In a typical experiment, we found that in the oblique dendrites near the main shaft, the spike-evoked signal for 10 bAPs was $1.53 \pm 0.5 \% \Delta F / F(n=8$ cells $)$. Typical background levels under oblique dendrites (Fig. $8 A$ ) were $\sim 70 \%$ of the fluorescence in the dendrite. Correcting for this background increased the amplitudes to $5.6 \pm 1.6 \% \Delta F / F$. Using the calibration determined in Figure 5, we estimate that a single bAP generates a $\left[\mathrm{Na}^{+}\right]_{\mathrm{i}}$ increase of $0.13 \mathrm{mM}$. In three experiments, we measured the bAP-evoked sodium change simultaneously using both ANG-2 and SBFI in the pipette (Miyazaki and Ross, 2015) and found that a single bAP evoked a sodium change of $0.23 \mathrm{~mm}$ using SBFI (data not shown). Since there was significant variation among cells and variation in the correction for background fluorescence, we consider the difference between this value and the value obtained with ANG-2 to be insignificant and both estimates were close to the value $(0.2 \mathrm{~mm})$ estimated previously (Rose et al., 1999) using SBFI in two-photon measurements that need no correction for background fluorescence. Our fluorescence mea-

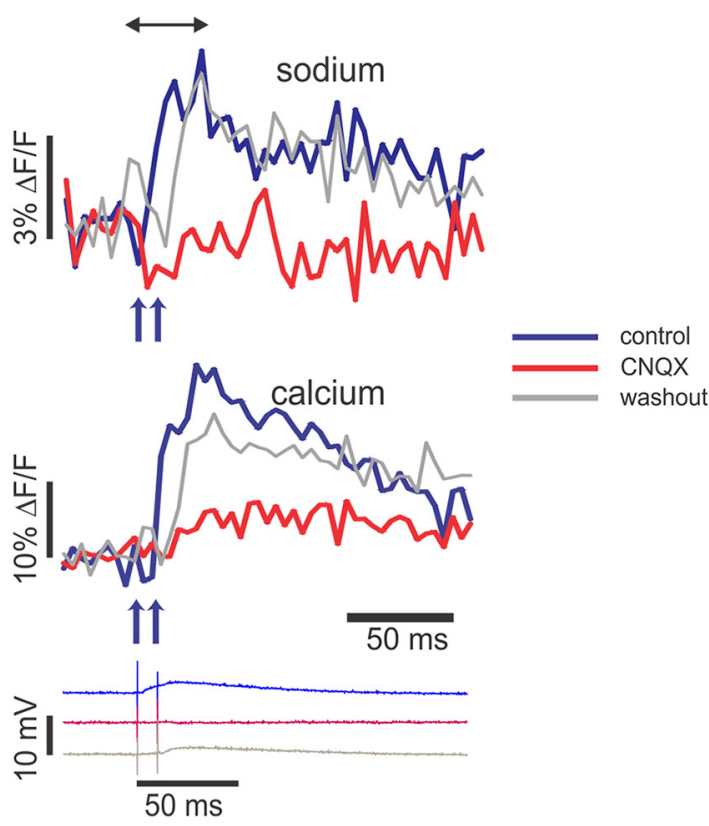

Sodium

Calcium

Figure 6. Both synaptically activated sodium and calcium signals are mostly blocked by the AMPA-receptor antagonist CNQX. $\boldsymbol{A}$, Experiment testing the effect of CNQX. The image shows a section of dendrite and an ROI that might include several spines. Sodium and calcium signals were evoked by a pair of synaptic stimuli separated by $10 \mathrm{~ms}$. Addition of $5 \mu \mathrm{m}$ CNQX blocked almost blocked, but some calcium response remained. In three of these experiments, there was washout of CNQX (one shown in $\boldsymbol{A}$ ); in seven experiments, there was no clear washout. ACSF contained $1 \mathrm{~mm} \mathrm{Mg}{ }^{2+}$.

surements were too insensitive to detect bAP signals of this magnitude in the spines above noise level, which corresponds to previous two-photon imaging results (Rose and Konnerth, 2001). In addition, the image of the fluorescence change (Fig. 8A) shows no localized hot spots in the dendrites that might correspond to locations with high densities of sodium channels activated by bAPs (e.g., if there were clusters on spine heads). A spike-evoked hot spot was found in the axon initial segment (AIS; Kole et al., 2008; Fleidervish et al., 2010) corresponding to the known site of bAP initiation (Stuart and Sakmann, 1994). From these results, it is clear that a single bAP fluorescence change in a spine region $(0.5 \%)$ is $<3 \%$ of the $24 \% \Delta F / F$ change evoked by synaptic activation (see above).

In a second experiment, we used a quaternary lidocaine derivative QX-314 to block sodium channels (Connors and Prince, 1982). We included $1 \mathrm{~mm}$ QX-314 in the patch pipette along with the indicators and we waited $\geq 30$ min before making optical measurements to allow the anesthetic to reach the dendritic region under examination. At this time, bAPs could no longer be evoked with intrasomatic stimulation. However, we were still 
A
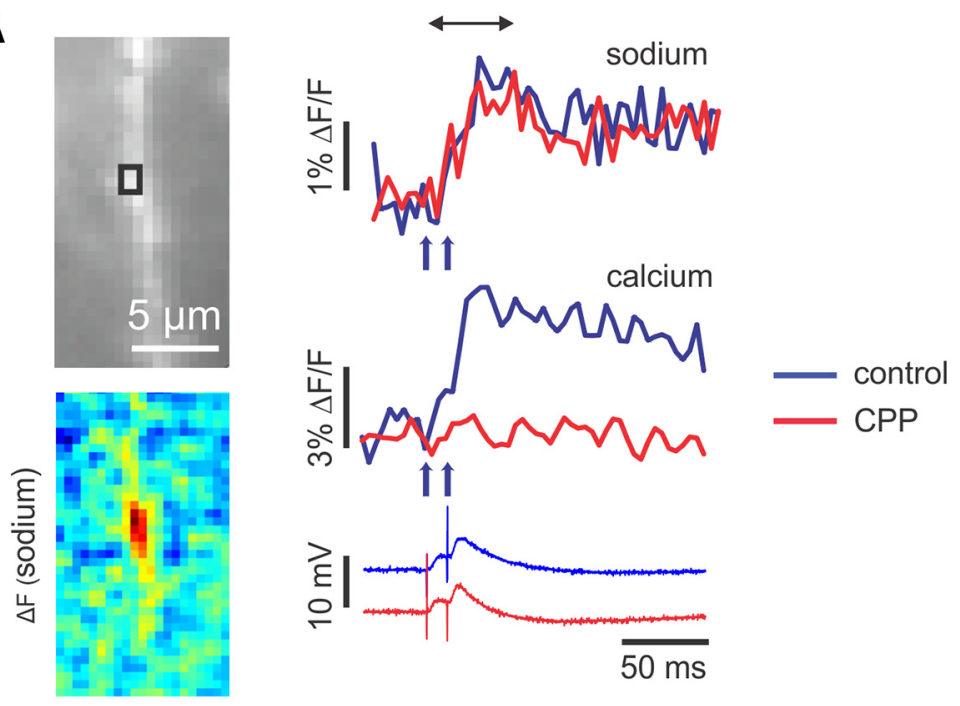

B

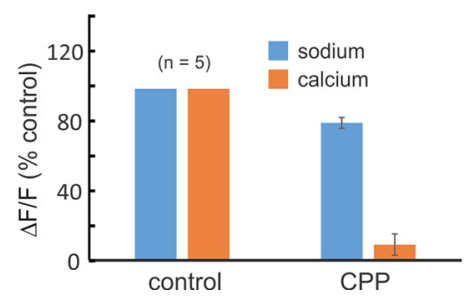

C

$\mathrm{Mg}^{2+}$ block, allowing sodium to enter through the NMDA receptor (Rose and Konnerth, 2001). To test this possibility, we compared the sodium signals evoked in consecutive trials where bAPs were generated or not following synaptic stimulation (Fig. 8C). There was no significant difference in the sodium changes in the two conditions, indicating that the spike contribution was relatively small compared with the synaptic signal. At the same time, we could detect an increased calcium transient in the spine from the bAP, showing that the spike reached the spine. This is a direct demonstration of how spine $\left[\mathrm{Ca}^{2+}\right]_{\mathrm{i}}$ reports coincidence of presynaptic and postsynaptic activity while spine $\left[\mathrm{Na}^{+}\right]_{\mathrm{i}}$ does not. The spine is able to generate two largely independent signals, one for the reliable transmission of electrical information and another one to signal events of special relevance, potentially inducing synaptic plasticity.

In some experiments (see Fig. 10B), we found that the generation of a bAP by the EPSP was associated with the generation of a slow plateau potential. In these cases, we detected larger and slower $\left[\mathrm{Na}^{+}\right]_{\mathrm{i}}$ increases. These increases were not due to the spike directly opening NMDA receptors by relieving the $\mathrm{Mg}^{2+}$ block because the $\left[\mathrm{Na}^{+}\right]_{\mathrm{i}}$ increases were too slow (Kampa et al., 2004). One possibility is that the bAP helped to initiate the NMDA spike.

\section{Sodium removal by diffusion}

The rapid removal of sodium from the spine following synaptic stimulation (Fig.

able to detect synaptically activated $\left[\mathrm{Na}^{+}\right]_{\mathrm{i}}$ increases (mean \pm SEM, $8.5 \pm 1.5 \% \Delta F / F)$ of comparable magnitude to the signals in cells without QX-314 (mean \pm SEM, $10.1 \pm 1.6 \% \Delta F / F$; Fig. $8 B)$. This result also suggests that a $\left[\mathrm{Na}^{+}\right]_{\mathrm{i}}$ increase due to synaptic activation of a persistent sodium current in the spine (Mittmann et al., 1997) is small since these channels are also blocked by QX-314 (Connors and Prince, 1982). A weakness of this experiment is that we are comparing two sets of cells without being able to determine whether the conditions were the same in each case. In similar experiments, including QX-314 in the pipette did not alter synaptically activated calcium transients (Grunditz et al., 2008), arguing that VGSCs do not significantly affect calcium entry through either VGCCs or NMDA receptors. Another, less direct, argument against a significant contribution from the persistent current, is that previously Fleidervish et al. (2010) found that in the axon hillock region activation of the persistent current, for a time comparable to the duration of a synaptic potential, generated a smaller $\left[\mathrm{Na}^{+}\right]_{\mathrm{i}}$ increase than an action potential. Since the spine spike signal is small, this suggests that the spine persistent current also is small. Nevertheless, we cannot rule out the possibility that a small contribution to the EPSP from this kind of conductance as found in some glutamate uncaging experiments (Araya et al., 2007).

A third possibility is that bAPs in dendritic spines could indirectly increase the $\left[\mathrm{Na}^{+}\right]_{\mathrm{i}}$ in the spine by rapidly relieving the
4) contrasts with the slow removal of sodium from the dendrites following a train of bAPs (Fig. 8A), as shown in previous experiments (Rose et al., 1999; Fleidervish et al., 2010). The slow removal is due to a membrane pump (Rose et al., 1999). However, the much faster removal from the spine more closely resembles the removal from the AIS and node of Ranvier, where diffusion from a localized source was shown to be responsible (Fleidervish et al., 2010). Diffusion is not a significant mechanism to remove sodium from the dendrites following bAPs since there is almost no concentration gradient in that region after spikes are evoked. To test the idea that diffusion is critical in removing sodium from spines, we constructed a simple computational model (Fig. 9A) using the NEURON simulation platform (Hines and Carnevale, 2001). The model consists of a spine head, spine neck, and a dendritic segment. Dimensions were determined from published estimates (Svoboda et al., 1996; Arellano et al., 2007; Takasaki and Sabatini, 2014). We assume that sodium enters the spine head during an EPSC dominated by AMPA conductance with a weak NMDA-receptor contribution consistent with the small effect of CPP on the $\left[\mathrm{Na}^{+}\right]_{\mathrm{i}}$ increase (Fig. $7 B$ ) and is removed by diffusion out the spine calculated using a diffusion constant of 0.6 $\mu \mathrm{m}^{2} / \mathrm{ms}$ (Kushmerick and Podolsky, 1969). To simplify the model, we assume no other membrane conductances, no membrane pumps, and no change in driving force following sodium 
entry. Details are in the legend of Figure 9. The model shows that following synaptic stimulation, sodium would diffuse out the spine neck with a half-removal time from the peak of $15 \mathrm{~ms}$, quite consistent with the measured value $(16.6 \pm 4.5 \mathrm{~ms})$. The slower NMDA component would add $<3$ ms to the half-recovery time. At the spine neck and in the nearby dendrite, the $\left[\mathrm{Na}^{+}\right]_{\mathrm{i}}$ would rise with a delay and would fall more slowly than at the spine head. Interestingly, the model reproduced the same sodium decay kinetics seen in the spine head (Figs. 3, 4). The decay is fast as long as the dendritic $\left[\mathrm{Na}^{+}\right]_{\mathrm{i}}$ is low, acting as an efficient sink. Dissipation of the local sodium accumulation along the thin dendrite is a slower process. We also constructed models with variations in the morphological parameters within previously determined ranges (Fig. 9B). In these models, the half-removal time in the spine head varied but not far from the value in Figure 9A. There were two exceptions. When the neck diameter was $0.1 \mu \mathrm{m}$ (at the low end of observed values), the halfrecovery time was significantly slower than the observed value, suggesting that we were not detecting signals from smaller spines with such narrow necks. This is reasonable since we expect weaker, possibly undetectable, signals from smaller spines. Also, when the sodium diffusion constant in the neck was smaller than the generally accepted value (Kushmerick and Podolsky, 1969), the half-recovery time was significantly slower than the observed value. This suggests that the diffusion (or resistance) properties of the spine neck are not different from those found in other cellular compartments.

Previously, spine-neck resistance was estimated in fluorescence recovery after photobleaching (FRAP) experiments where exogenously introduced fluorescein dextrans diffused rapidly through spine necks with a time constant consistent with low neck resistance (Svoboda et al., 1996; Takasaki and Sabatini, 2014). Potential criticisms of these experiments are (1) that they measured the diffusion of an exogenous, large, uncharged molecule and not a physiological ion (Bloodgood et al., 2009), and (2) that the photobleaching pulse was a nonphysiological stimulus and possibly damaging to the spine (Koester et al., 1999). Our experiments avoided these criticisms. Although we measure the time course of indicator fluorescence, this accurately reflects the time course of sodium diffusion since indicator concentration is much lower than $\left[\mathrm{Na}^{+}\right]_{\mathrm{i}}$ and the indicator $K_{\mathrm{d}}$ is much higher than the $\left[\mathrm{Na}^{+}\right]_{\mathrm{i}}$ (Fig. 5). We applied the calculation framework of the FRAP experiments (Svoboda et al., 1996) to our data using the formula $R_{N}=\tau \rho_{i} D_{N a} / V_{n}$, where: $R_{N}$ is spine-neck resistance, $\tau$ is time constant of decay, $\rho_{i}$ is specific axoplasmic resistance, $D_{\mathrm{Na}}$ is diffusion constant for sodium in cytoplasm, and $V_{n}$ is spine head volume. We estimate that $\tau=23 \mathrm{~ms}$ (from the single-spine events in our data, assuming an exponential decay; Fig. 4; the recovery time constant for an impulse jump in $\left[\mathrm{Na}^{+}\right]_{\mathrm{i}}$, which would cor- respond to the FRAP experiments, is faster than this value since there is some sodium entry through both AMPA receptors and NMDA receptors during the falling phase of the signal); $\rho_{i}=180$ $\Omega \cdot \mathrm{cm}$ (Golding et al., 2005); $D_{\mathrm{Na}}=6.0 \times 10^{-6} \mathrm{~cm}^{2} / \mathrm{s}$ (Kushmerick and Podolsky, 1969); $V_{n}=0.1 \mu \mathrm{m}^{3}$ [from the center of published values: (Svoboda et al., 1996) range, 0.1-0.6 $\mathrm{mm}^{3}$; (Takasaki and Sabatini, 2014) range, 0.01-0.1 $\mu \mathrm{m}^{3}$; (Arellano et al., 2007) range, $\left.0.01-0.3 \mu \mathrm{m}^{3}\right]$. This calculation yields $R_{N}=250$ $\mathrm{M} \Omega$. The biggest uncertainty is spine-neck volume. If we are biased toward larger spines (Svoboda et al., 1996), then estimates for $R_{N}$ would be smaller, e.g., if $V_{n}$ is $0.25 \mu \mathrm{m}^{3}$ (as we assumed in our model), then $R_{N}$ will be $92 \mathrm{M} \Omega$, which is in the range of values (4-150 M $\Omega$ ) previously estimated (Svoboda et al., 1996).

\section{Discussion}

An important result of these experiments is the demonstration that sodium imaging can be used to detect and analyze properties of synaptic transmission at the single-spine level. In particular, we can measure AMPA-receptor mechanisms, which are not easily revealed with calcium imaging. These signals can be combined with calcium imaging in a way that directly compares the two changes in single trials, avoiding the complications due to well known variations in synaptic responses to constant stimuli (Allen 
A

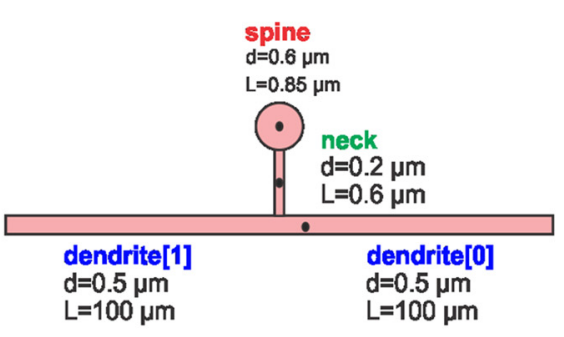

B
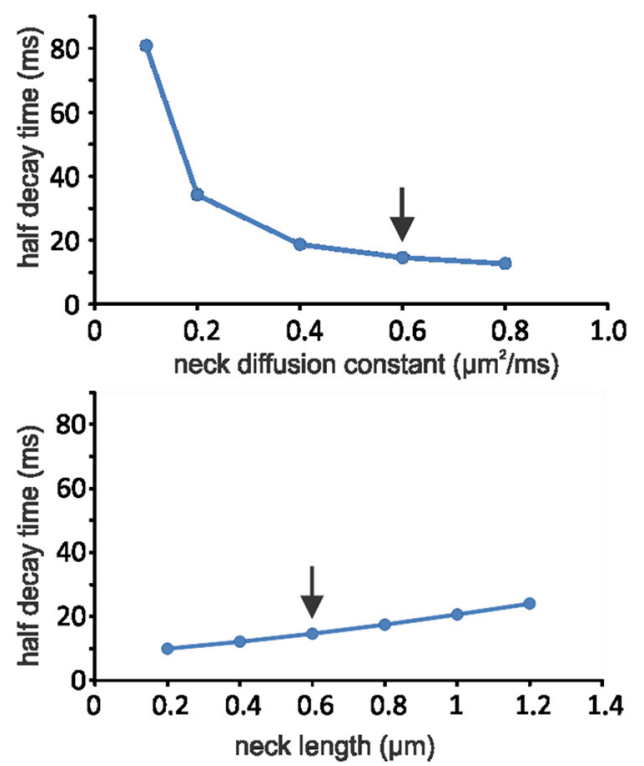
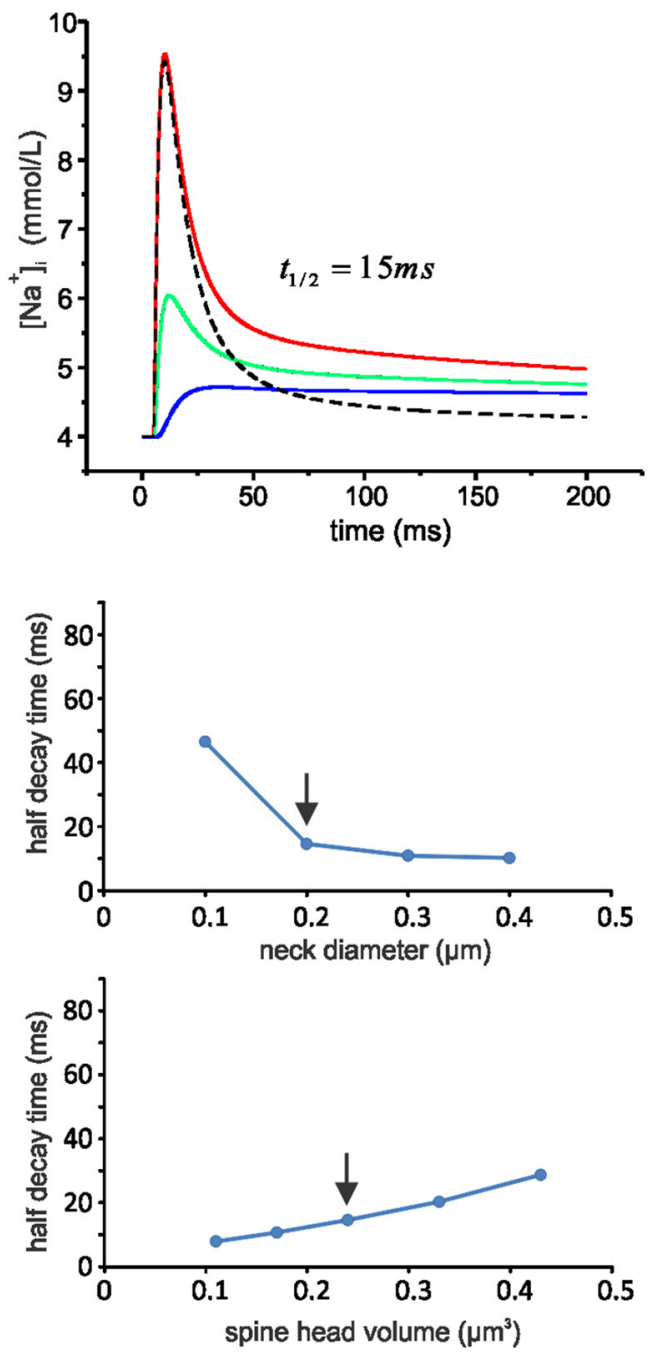

Figure 9. Computational model of sodium entry into and diffusion from a dendritic spine. $\boldsymbol{A}$, Components of the model: spine head, spine neck, two dendritic segments. The starting dimensions are shown next to each component. Using the NEURON platform, the sodium conductance generating the EPSC was modeled as a point process on the spine head using $g_{\text {AMPA }}(t)=g_{\mathrm{A}}{ }^{*}\left[\exp \left(-t / t_{1}\right)-\exp \left(-t / t_{2}\right)\right], t_{1}=2 \mathrm{~ms}, t_{2}=0.5 \mathrm{~ms}$ (Grunditz et al., 2008$) ; g_{\mathrm{NMDA}}(t)=g_{\mathrm{N}}{ }^{*}[1-(1 /[1+\mathrm{k} /[\mathrm{Mg}]])] * \exp \left(-t / t_{3}\right) *\left[1-\exp \left(-t / t_{4}\right)\right], t_{3}=71 \mathrm{~ms}, t_{4}=13.2 \mathrm{~ms}$, $k=1.07^{*} \exp \left(0.057^{*} V\right)$, where $V$ is voltage in $\mathrm{mV}$ and $[\mathrm{Mg}]=2 \mathrm{~mm}(\mathrm{McC}$ ormick et al., 1993$)$; temperature, $22^{\circ} \mathrm{C} . \mathrm{g}_{\mathrm{A}}$ and $\mathrm{g}_{\mathrm{N}}$ are constants that were adjusted to give $\sim 5 \mathrm{~mm}$ peak $\left[\mathrm{Na}{ }^{+}\right]_{\mathrm{i}}$ at the spine head. Resting $\left[\mathrm{Na}^{+}\right]_{\mathrm{i}}=4 \mathrm{~mm}$ and $E_{\mathrm{Na}}=+40 \mathrm{mV}$. The only mechanisms affecting $\left[\mathrm{Na}^{+}\right]_{\mathrm{i}}$ were entry through AMPA and NMDA receptors and diffusion. The traces in the modeled concentrations were taken from the locations marked with a black dot; on the dendrite, this point was $3 \mu \mathrm{m}$ from the neck. The time to half decay in the spine head was $15 \mathrm{~ms}$. Removing the NMDA conductance (dashed black line) had almost no effect on the fast component of the response but decreased the slow component; the half-removal time was reduced by 2.4 ms. $\boldsymbol{B}$, Variations in the half-decay time in models where only one of four parameters was varied; the other parameters were as in $\boldsymbol{A}$. The arrows point to the starting values in $\boldsymbol{A}$. Most of the models predicted half-decay times within the range of measured values with two exceptions: small spine-neck diameter and small diffusion constant.

and Stevens, 1994). The technical aspects of this method, using rapid switching of excitation wavelengths to selectively excite two different indicator dyes, were described previously (Miyazaki and Ross, 2015).

\section{Source and magnitude of synaptically activated} sodium increases

Pharmacological experiments (Figs. 6, 7) showed that most of the subthreshold localized sodium response remained and most of the calcium response was blocked in the presence of CPP. There was little contribution of sodium entry through VGSCs to the synaptic sodium response (Fig. 8). These results suggest that most of the $\left[\mathrm{Na}^{+}\right]_{\mathrm{i}}$ increase comes from entry through AMPA receptors and most of the $\left[\mathrm{Ca}^{2+}\right]_{\mathrm{i}}$ increase comes from entry through NMDA receptors. Consistent with this conclusion, we found that the rise time of the $\left[\mathrm{Na}^{+}\right]_{\mathrm{i}}$ increase was faster than the rise time of the $\left[\mathrm{Ca}^{2+}\right]_{\mathrm{i}}$ increase, which matches the kinetics of these recep- tors (Sah et al., 1990). The small amount of sodium entry through NMDA receptors necessarily follows the time course of calcium entry through these receptors and probably contributes to the shoulder on the falling phase of the sodium signal (Figs. 4, 9A). Previous claims (Rose and Konnerth, 2001) that most synaptically activated $\left[\mathrm{Na}^{+}\right]_{\mathrm{i}}$ increase is through NMDA receptors do not correspond with these results. Calcium entry through NMDA receptors is important biochemically, but does not contribute significant charge to the EPSP (Schneggenburger et al., 1993).

Whether VGSCs contribute importantly in generating the synaptic potential is controversial. Immunological evidence for the presence of sodium channels in pyramidal neuron spines is absent (Lorincz and Nusser, 2010). We found that a single bAP generates $<3 \%$ of the sodium change in a spine that a single synaptic response evokes. Since sodium entry is the major generator of the voltage response, this result suggests that voltage-gated sodium entry makes a minor contribution to the EPSP. These 
A

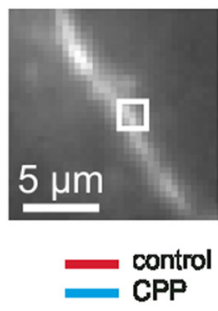

C

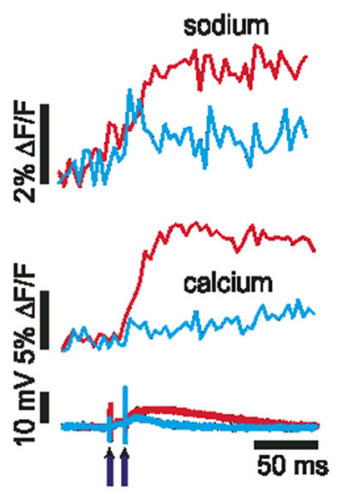

B

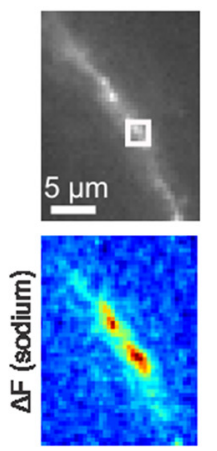

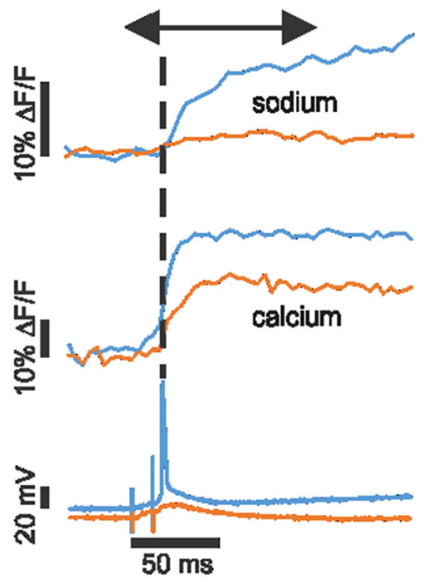

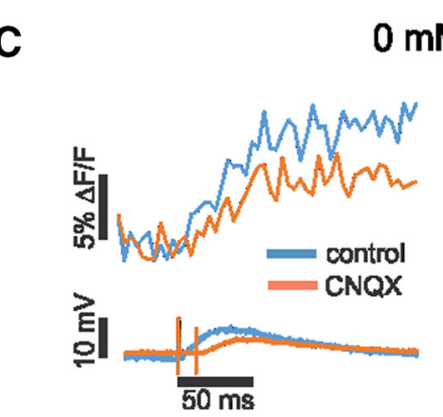

$0 \mathrm{mM} \mathrm{Mg}^{2+}$

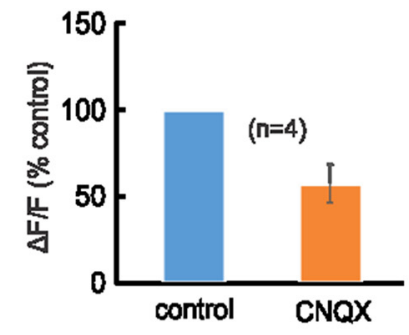

Figure 10. Sodium signals from activation of NMDA receptors. $A$, In a few experiments, double stimulation generated a long-lasting sodium signal associated with a long-lasting EPSP. Since the long-lasting response and the $\left[\mathrm{Ca}^{2+}\right]_{i}$ change were blocked by $10 \mu \mathrm{M} C P P$, we interpret this response as an NMDA spike. $B$, Sometimes large $\left[\mathrm{Na}^{+}\right]_{i}$ and $\left[\mathrm{Ca}^{2+}\right]_{i}$ changes can be initiated by a bAP. In the control trial (orange traces, without bAP) synaptic activation evoked a $\left[\mathrm{Ca}^{2+}\right]_{\mathrm{i}}$ change and a very small $\left[\mathrm{Na}^{+}\right]_{\mathrm{i}}$ change. In another trial (with bAP, blue traces) large sodium and calcium traces were evoked. The flat top on the calcium trace suggests that the bis-fura- 2 response was saturated. The large responses in $\boldsymbol{A}$ and $\boldsymbol{B}$ probably reflect regenerative NMDA-receptor activation. $\boldsymbol{C}$, Large, long-lasting sodium signals were detected following synaptic stimulation in ACSF containing $0 \mathrm{~mm} \mathrm{Mg}^{2+}$. These signals were only weakly reduced in CNQX ( $p=0.04$ ), showing they resulted from sodium entry through NMDA receptors. All these signals extended over a few micrometers so they did not come from activation of single spines.

results are consistent with some previous experiments (Palmer and Stuart, 2009) but contrast with experiments (Araya et al., 2007) where TTX reduced the uncaging-evoked synaptic potentials recorded in the soma of pyramidal neurons, although it is possible that our experiments were not sensitive enough to detect this contribution. Using related uncaging techniques, VGSCs have been found to contribute to the synaptic response in some olfactory neuron spines (Bywalez et al., 2015), which are reported to be larger than pyramidal neuron spines.

If, as we find, almost all of the synaptic sodium entry in most experiments is through AMPA receptors, and this sodium entry is the source of the EPSP, then it is unlikely that the EPSP is amplified by nonlinear currents through NMDA receptors and VGSCs, as has been suggested previously (Harnett et al., 2012). However, in some trials, we detected larger, long-lasting sodium increases and plateau potentials, which have a regenerative component (Fig. 10A,B). Addition of CPP eliminated the plateau and the slower sodium signal, suggesting that both were generated by a small NMDA spike (Schiller and Schiller, 2001). NMDA spikes and plateau potentials have been examined in many recent experiments (Antic et al., 2010). The conditions for evoking these events are still unclear, but they do not appear to contribute to most subthreshold responses.

In seven cells, we were able to detect clean sodium and calcium signals that clearly were separately derived from nine single spines and nearby dendrites. The signals from these cells gave consistent results. The sodium signals from the spines rose rapidly in $<10 \mathrm{~ms}$ and fell to half amplitude in $\sim 16 \mathrm{~ms}$. The synap- tically activated sodium signal in the nine spines had a peak fluorescence change $(\Delta F / F)$ of $\sim 24 \%$ after making crude corrections for background fluorescence. Based on our calibration (Fig. 5 ), this corresponds to an increase of $\sim 5 \mathrm{~mm}$, which would almost double the resting concentration often assumed in neurons (Rose, 2002). This increase would cause a modest decrease in the driving force for sodium. Therefore, a second EPSP, following immediately, will generate a smaller amount of sodium entry than the first one. However, the recovery time is very rapid so the resting concentration will be quickly restored. Following multiple EPSPs at the same synapse, the driving force will be further reduced and the recovery time will be extended as the concentration gradient for sodium is reduced. Also, if several nearby spines were activated, the buildup of sodium in the dendrite would be greater than from activating a single spine. This buildup would oppose diffusion out of the spine leading to a higher concentration compared with the activation of a single spine.

\section{Sodium diffusion and spine-neck resistance}

The rapid decline of $\left[\mathrm{Na}^{+}\right]_{\mathrm{i}}$ in the spine and slower rise in the dendrite is consistent with sodium diffusion through the spine neck into the dendrite and was reproduced in a simulation that only considered diffusion and no membrane pump in the removal process (Fig. 9). This rapid time course has important implications. It demonstrates that diffusion is the main mechanism removing charge from the spine after synaptic activation. Sodium pumping through the plasma membrane, examined in conditions where diffusion is minimal (e.g., following bAPs in the 
dendrites), has a removal time constant of seconds (Rose et al., 1999), $>100 \times$ slower than the removal rate in the spine.

Removal with a half-decay time of 16 ms only has a small effect on the peak $\left[\mathrm{Na}^{+}\right]_{\mathrm{i}}$ and EPSP amplitude determined only by activation of AMPA receptors since the duration of this conductance is only a few milliseconds (Sah et al., 1990). However, activation of NMDA receptors is slower. Since the duration of the EPSP in spines in these cells is short ( $\sim 6 \mathrm{~ms}$ using VSDs or nanopipette recording; Popovic et al., 2015; Jayant et al., 2017), the $\mathrm{Mg}^{2+}$ block will be restored quickly (in conditions where plateau potentials are not generated), limiting the time when NMDA receptors are open. Even in the time when these receptors are open, there will be significant removal of sodium by diffusion, limiting the contribution of NMDA receptors to the $\left[\mathrm{Na}^{+}\right]_{\mathrm{i}}$ buildup.

The rapid diffusion out the spine neck of synaptically elevated sodium is also consistent with a low spine-neck resistance. Our simulation (Fig. 9) suggests that if the sodium diffusion constant in the spine neck was significantly smaller than found experimentally in the cytoplasm of other cells (presumably corresponding to a higher neck resistance), it would lead to a much slower recovery time. Other simulations and VSD measurements (Popovic et al., 2015) suggest that if the electrical properties of the spine neck correspond to properties in other neuronal compartments, then the neck resistance would be $<50 \mathrm{M} \Omega$. Analysis of spine-neck resistance using the FRAP approach gave the same result in some experiments (Svoboda et al., 1996; Tønnesen et al., 2014) and slightly higher in others (Acker et al., 2016). Other recent experiments using calcium measurements (Harnett et al., 2012) or direct electrical recording (Jayant et al., 2017) gave higher values.

It is important to note that this analysis assumes the basic hypotheses of cable theory and linear diffusion. It does not consider possible complications from electrodiffusion (Qian and Sejnowski, 1989; Holcman and Yuste, 2015). These include (1) changes in the EPSP driving force due to $\left[\mathrm{Na}^{+}\right]_{\mathrm{i}}$ change, (2) changes in the longitudinal driving force due to $\left[\mathrm{Na}^{+}\right]_{\mathrm{i}}$ gradients, and (3) differences in axial resistance for different ions.

\section{Spine-calcium changes}

Although it was not our main objective to examine synaptically activated $\left[\mathrm{Ca}^{2+}\right]_{\mathrm{i}}$ changes, some of our results can be compared with previous observations about such changes. We found that $\sim 90 \%$ of this component could be blocked by CPP, indicating that entry through VGCCs was small. The role of sodium imaging in these experiments (Fig. 7A) was to confirm that application of the blockers did not significantly reduce the synaptic current driving the EPSP that opened the VGCCs, a result consistent with the small effect of CPP on the synaptic potential. This result agrees with earlier experiments on pyramidal neurons (Emptage et al., 1999; Yuste et al., 1999) and with more recent related research (Grunditz et al., 2008; Popovic et al., 2015). Other experiments (Bloodgood and Sabatini, 2005; Bloodgood et al., 2009) that used two-photon glutamate uncaging to activate spines, found a larger VGCC component. One way to reconcile these results is to postulate that on average the uncaging experiments generated a slightly larger EPSP in the spine than direct synaptic activation generated in our experiments. Another possibility is that the slight somatic hyperpolarization we sometimes imposed to prevent firing reduced the activation of VGCCs in our experiments.

The nearly consistent half-recovery times of the nine spines might suggest that neck and other spine properties are homogeneous. However, the modeling results suggest that a wide range of morphological parameters could result in recovery times within the range we measured. Nevertheless, neck properties may be more varied than we found. Signaling in long-neck spines (Bloodgood and Sabatini, 2005; Araya et al., 2006) or stubby spines might be different from signaling in the spines we examined. We made no effort to select different types of spines. In addition, recent results indicate that spine properties may be plastic, e.g., changing neck resistance depending on previous activity (Bloodgood and Sabatini, 2005; Grunditz et al., 2008; Araya et al., 2014; Tønnesen et al., 2014). In some experiments, we observed local regenerative events (Fig. 10A), which may have been triggered by simultaneous activation of $>1$ synapse. These variations may be explored in the future when sodium imaging achieves higher signal-to-noise ratios in synaptic experiments and the success rates in these experiments improve. Until now there have been no published reports of sodium imaging on single spines using two-photon recording, which may be necessary to make these discriminations. Better indicators would be a big step forward.

\section{References}

Acker CD, Hoyos E, Loew LM (2016) EPSPs measured in proximal dendritic spines of cortical pyramidal neurons. eNeuro 3:pii:ENEURO.005015.2016. CrossRef Medline.

Allen C, Stevens CF (1994) An evaluation of causes for unreliability of synaptic transmission. Proc Natl Acad Sci U S A 91:10380-10383. CrossRef Medline

Antic SD, Zhou WL, Moore AR, Short SM, Ikonomu KD (2010) The decade of the dendritic NMDA spike. J Neurosci Res 88:2991-3001. CrossRef Medline

Araya R, Jiang J, Eisenthal KB, Yuste R (2006) The spine neck filters membrane potentials. Proc Natl Acad Sci U S A 103:17961-17966. CrossRef Medline

Araya R, Nikolenko V, Eisenthal KB, Yuste R (2007) Sodium channels amplify spine potentials. Proc Natl Acad Sci U S A 104:12347-12352. CrossRef Medline

Araya R, Vogels TP, Yuste R (2014) Activity-dependent dendritic spine neck changes are correlated with synaptic strength. Proc Natl Acad Sci U S A 111:E2895-E2904. CrossRef Medline

Arellano JI, Benavides-Piccione R, Defelipe J, Yuste R (2007) Ultrastructure of dendritic spines: correlation between synaptic and spine morphologies. Front Neurosci 1:131-143. CrossRef Medline

Bender KJ, Trussell LO (2009) Axon initial segment Ca2+ channels influence action potential generation and timing. Neuron 61:259-271. CrossRef Medline

Bloodgood BL, Sabatini BL (2005) Neuronal activity regulates diffusion across the neck of dendritic spines. Science 310:866-869. CrossRef Medline

Bloodgood BL, Sabatini BL (2007) Nonlinear regulation of unitary synaptic signals by $\mathrm{CaV} 2.3$ voltage-sensitive calcium channels located in dendritic spines. Neuron 53:249-260. CrossRef Medline

Bloodgood BL, Giessel AJ, Sabatini BL (2009) Biphasic synaptic Ca influx arising from compartmentalized electrical signals in dendritic spines. PLoS Biol 7:e1000190. CrossRef Medline

Bywalez WG, Patirniche D, Rupprecht V, Stemmler M, Herz AV, Pálfi D, Rózsa B, Egger V (2015) Local postsynaptic voltage-gated sodium channel activation in dendritic spines of olfactory bulb granule cells. Neuron 85:590-601. CrossRef Medline

Callaway JC, Ross WN (1997) Spatial distribution of synaptically activated sodium concentration changes in cerebellar Purkinje neurons. J Neurophysiol 77:145-152. Medline

Chalifoux JR, Carter AG (2011) Glutamate spillover promotes the generation of NMDA Spikes. J Neurosci 31:16435-16446. CrossRef Medline

Connors BW, Prince DA (1982) Effects of local anesthetic QX-314 on the membrane properties of hippocampal pyramidal neurons. J Pharmacol Exp Ther 220:476-481. Medline

Ding F, O'Donnell J, Xu Q, Kang N, Goldman N, Nedergaard M (2016) Changes in the composition of brain interstitial ions control the sleepwake cycle. Science 352:550-555. CrossRef Medline

Emptage N, Bliss TV, Fine A (1999) Single synaptic events evoke NMDA receptor-mediated release of calcium from internal stores in hippocampal dendritic spines. Neuron 22:115-124. CrossRef Medline 
Fleidervish IA, Lasser-Ross N, Gutnick MJ, Ross WN (2010) Na+ imaging reveals little difference in action potential-evoked $\mathrm{Na}+$ influx between axon and soma. Nat Neurosci 13:852-860. CrossRef Medline

Golding NL, Mickus TJ, Katz Y, Kath WL, Spruston N (2005) Factors mediating powerful voltage attenuation along CA1 pyramidal neuron dendrites. J Physiol 568:69-82. CrossRef Medline

Grunditz A, Holbro N, Tian L, Zuo Y, Oertner TG (2008) Spine neck plasticity controls postsynaptic calcium signals through electrical compartmentalization. J Neurosci 28:13457-13466. CrossRef Medline

Grynkiewicz G, Poenie M, Tsien RY (1985) A new generation of Ca2+ indicators with greatly improved fluorescence properties. J Biol Chem 260: 3440-3450. Medline

Harnett MT, Makara JK, Spruston N, Kath WL, Magee JC (2012) Synaptic amplification by dendritic spines enhances input cooperativity. Nature 491:599-602. CrossRef Medline

Helmchen F, Imoto K, Sakmann B (1996) Ca2+ buffering and action potential-evoked $\mathrm{Ca} 2+$ signaling in dendrites of pyramidal neurons. Biophys J 70:1069-1081. CrossRef Medline

Hines ML, Carnevale NT (2001) NEURON: a tool for neuroscientists. Neuroscientist 7:123-135. CrossRef Medline

Holcman D, Yuste R (2015) The new nanophysiology: regulation of ionic flow in neuronal subcompartments. Nat Rev Neurosci 16:685-692. CrossRef Medline

Jaffe DB, Johnston D, Lasser-Ross N, Lisman JE, Miyakawa H, Ross WN (1992) The spread of $\mathrm{Na}+$ spikes determines the pattern of dendritic $\mathrm{Ca} 2+$ entry into hippocampal neurons. Nature 357:244-246. CrossRef Medline

Jayant K, Hirtz JJ, Plante IJ, Tsai DM, De Boer WD, Semonche A, Peterka DS, Owen JS, Sahin O, Shepard KL, Yuste R (2017) Targeted intracellular voltage recordings from dendritic spines using quantum-dot-coated nanopipettes. Nat Nanotechnol 12:335-342. CrossRef Medline

Kampa BM, Clements J, Jonas P, Stuart GJ (2004) Kinetics of $\mathrm{Mg}^{2+}$ unblock of NMDA receptors: implications for spike-timing dependent synaptic plasticity. J Physiol 556:337-345. CrossRef Medline

Knöpfel T, Anchisi D, Alojado ME, Tempia F, Strata P (2000) Elevation of intradendritic sodium concentration mediated by synaptic activation of metabotropic glutamate receptors in cerebellar Purkinje cells. Eur J Neurosci 12:2199-2204. CrossRef Medline

Koester HJ, Baur D, Uhl R, Hell SW (1999) Ca2 + fluorescence imaging with pico- and femtosecond two-photon excitation: signal and photodamage. Biophys J 77:2226-2236. CrossRef Medline

Kole MH, Ilschner SU, Kampa BM, Williams SR, Ruben PC, Stuart GJ (2008) Action potential generation requires a high sodium channel density in the axon initial segment. Nat Neurosci 11:178-186. CrossRef Medline

Kovalchuk Y, Eilers J, Lisman J, Konnerth A (2000) NMDA receptormediated subthreshold $\mathrm{Ca} 2+$ signals in spines of hippocampal neurons 20:1791-1799.

Kushmerick MJ, Podolsky RJ (1969) Ionic mobility in muscle cells. Science 166:1297-1298. CrossRef Medline

Lasser-Ross N, Ross WN (1992) Imaging voltage and synaptically activated sodium transients in cerebellar Purkinje cells. Proc R Soc B Biol Sci 247: 35-39. CrossRef Medline

Lorincz A, Nusser Z (2010) Molecular identity of dendritic voltage-gated sodium channels. Science 328:906-909. CrossRef Medline

McCormick DA, Wang Z, Huguenard J (1993) Neurotransmitter control of neuronal activity and excitability. Cereb Cortex 3:387-398. CrossRef Medline

Mittmann T, Linton SM, Schwindt P, Crill W (1997) Evidence for persistent $\mathrm{Na}+$ current in apical dendrites of rat neocortical neurons from imaging of $\mathrm{Na}+$-sensitive dye. J Neurophysiol 78:1188-1192. Medline

Miyazaki K, Ross WN (2015) Simultaneous sodium and calcium imaging from dendrites and axons. eNeuro 2:pii:ENEURO.0092-15.2015. CrossRef Medline

Neher E, Augustine GJ (1992) Calcium gradients and buffers in bovine chromaffin cells. J Physiol 450:273-301. CrossRef Medline

Oertner TG, Sabatini BL, Nimchinsky EA, Svoboda K (2002) Facilitation at single synapses probed with optical quantal analysis. Nat Neurosci 5:657664. CrossRef Medline

Palmer LM, Stuart GJ (2009) Membrane potential changes in dendritic spines during action potentials and synaptic input. J Neurosci 29:68976903. CrossRef Medline

Popovic MA, Carnevale N, Rozsa B, Zecevic D (2015) Electrical behaviour of dendritic spines as revealed by voltage imaging. Nat Commun 6:8436. CrossRef Medline

Qian N, Sejnowski TJ (1989) An electro-diffusion model for computing membrane potentials and ionic concentrations in branching dendrites, spines and axons. Biol Cybern 62:1-15. CrossRef

Rose CR (2002) Na+ signals at central synapses. Neurosci 8:532-539. CrossRef Medline

Rose CR, Konnerth A (2001) NMDA receptor-mediated Na+ signals in spines and dendrites. J Neurosci 21:4207-4214. Medline

Rose CR, Kovalchuk Y, Eilers J, Konnerth A (1999) Two-photon Na+ imaging in spines and fine dendrites of central neurons. Pflugers Arch 439: 201-207. CrossRef Medline

Sabatini BL, Oertner TG, Svoboda K (2002) The life cycle of Ca2+ ions in dendritic spines. Neuron 33:439-452. CrossRef Medline

Sah P, Hestrin S, Nicoll RA (1990) Properties of excitatory postsynaptic currents recorded in vitro from rat hippocampal interneurones. J Physiol 430:605-616. CrossRef Medline

Schiller J, Schiller Y (2001) NMDA receptor-mediated dendritic spikes and coincident signal amplification. Curr Opin Neurobiol 11:343-348. CrossRef Medline

Schiller J, Major G, Koester HJ, Schiller Y (2000) NMDA spikes in basal dendrites of cortical pyramidal neurons. Nature 404:285-289. CrossRef Medline

Schneggenburger R, Zhou Z, Konnerth A, Neher E (1993) Fractional contribution of calcium to the cation current through glutamate receptor channels. Neuron 11:133-143. CrossRef Medline

Segev I, Rall W (1988) Computational study of an excitable dendritic spine. J Neurophysiol 60:499-523. Medline

Stevens CF, Wang Y (1995) Facilitation and depression at single central synapses. Neuron 14:795-802. CrossRef Medline

Stuart GJ, Sakmann B (1994) Active propagation of somatic action potentials into neocortical pyramidal cell dendrites. Nature 367:69-72. CrossRef Medline

Stuart GJ, Dodt HU, Sakmann B (1993) Patch-clamp recordings from the soma and dendrites of neurons in brain slices using infrared video microscopy. Pflugers Arch 423:511-518. CrossRef Medline

Svoboda K, Tank DW, Denk W (1996) Direct measurement of coupling between dendritic spines and shafts. Science 272:716-719. CrossRef Medline

Takasaki K, Sabatini BL (2014) Super-resolution 2-photon microscopy reveals that the morphology of each dendritic spine correlates with diffusive but not synaptic properties. Front Neuroanat 8:29. CrossRef Medline

Tønnesen J, Katona G, Rózsa B, Nägerl UV (2014) Spine neck plasticity regulates compartmentalization of synapses. Nat Neurosci 17:678-685. CrossRef Medline

Yuste R, Denk W (1995) Dendritic spines as basic functional units of neuronal integration. Nature 375:682-684. CrossRef Medline

Yuste R, Majewska A, Cash SS, Denk W (1999) Mechanisms of calcium influx into hippocampal spines: heterogeneity among spines, coincidence detection by NMDA receptors, and optical quantal analysis. J Neurosci 19:1976-1987. Medline 